\title{
SERAPAN HARA, PERTUMBUHAN DAN HASIL TANAMAN SAWI PAKCOY (BRASSICA RAPA L.) YANG DIBUDIDAYAKAN SECARA ORGANIK DENGAN APLIKASI VERMIKOMPOS
}

\author{
Nisma Ula Shoumi Rahmawati ${ }^{1}$ \\ ${ }^{1}$ Program Magister Pengelolaan Tanah dan Air, Fakultas Pertanian, Universitas \\ Brawijaya, \\ Jl. Veteran No. 1 Malang 65145, Jawa Timur, Indonesia \\ Korespondensi : nismaula74@gmail.com
}

\begin{abstract}
ABSTRAK
Kualitas vermikompos ditentukan oleh macam bahan media yang digunakan, tingkat kematangan, spesies cacing yang digunakan dan proses pembuatannya. Penelitian ini menggunakan tanaman sawi pakcoy (Brassica rapa L.). Tujuan Penelitian ini yaitu untuk menentukan dosis optimum tiga macam vermikompos terhadap serapan hara $\mathrm{N}, \mathrm{P}$ dan $\mathrm{K}$ dan respon pertumbuhan serta hasil tanaman sawi pakcoy (Brassica rapa L.). Penelitian dilakukan di lahan Pertanian di Desa Landungsari Kecamatan Dau Kabupaten Malang dengan ketinggian $\pm 544 \mathrm{~m}$ dpl. Penelitian ini merupakan percobaan lapang menggunakan RAK faktorial dengan kontrol. Faktor 1 : Macam Bahan Vermikompos, Faktor 2 : Dosis Aplikasi. Data yang dihasilkan dianalisis ANOVA dengan uji lanjut BNJ 5\% dan uji Dunnet 5\%. Analisis Regresi dilakukan untuk mencari dosis optimum vermikompos. Hasil penelitian menunjukkan, pertumbuhan dan produksi tanaman sawi pakcoy menggunakan vermikompos memperlihatkan hasil yang lebih tinggi dibandingkan dengan kontrol. Pada perlakuan $\mathrm{V}_{2} \mathrm{D}_{2}$ (sabut kelapa + kotoran sapi + seresah daun + jerami padi + sisa sayuran dengan dosis 10 ton ha- ${ }^{-1}$ ).
\end{abstract}

Kata kunci : serapan hara, pertumbuhan, hasil, sawi pakcoy organik, vermikompos

\section{ABSTRACT}

The quality of vermicompost is determined by the kinds of media materials used, the degree of maturity, the worm species used and the manufacturing process. In this study using plant pakkoy pakkoy (Brassica rapa L.). The purpose of this study was to determine the optimum dose of three kinds of vermicompost for $N, P$ and $K$ nutrient uptake and growth response and yield of mustard pakcoy (Brassica rapa L.). The research was conducted at Agricultural Land in Landungsari Village, Dau District of Malang Regency with height $\pm 544 \mathrm{~m}$ asl. This research is a field experiment using factorial randomized block design (RAK) with control. Factor 1: Various Vermicompost Materials Factor 2: Application Dose. The resulting data were analyzed variance (ANOVA) with 5\% BNJ and 5\% Dunnet. Regression analysis was performed to find the optimum dose of vermicompost. The results showed that the growth and production of mustard plant pakcoy using vermicompost showed higher yield compared to control. In the treatment of V2D2 (coconut husk + cow dung + leaf litter + rice straw + leftover vegetables with dose of 10 ton ha1).

Keywords: nutrient uptake, growth, yield, mustard pakcoy organic, vermicompost

\section{PENDAHULUAN}

Budidaya tanaman secara organik selain meningkatkan kualitas tanaman juga dapat mengatasi kemerosotan kesuburan tanah karena tanah akibat budidaya tanaman secara konvensional tanpa masukan bahan organik. Budidaya tanaman secara organik dicirikan oleh penggunaan pupuk organik sebagai pengganti pupuk kimia yang ramah lingkungan dan tidak merusak alam.

Pupuk organik yang juga banyak digunakan dalam budidaya tanaman secara organik adalah vermikompos. Vermikompos merupakan campuran media tumbuh 
cacing dan kotoran cacing (kascing) yang dihasilkan selama vermicomposting. Oleh karena itu vermikompos memiliki kandungan hara yang lebih tinnggi dari pada kompos konvensional, memiliki $\mathrm{C} / \mathrm{N}$ rasio rendah, porositas dan kapasitas menahan air yang tinggi. (Dominguez, 2004)

Hara N, P dan $\mathrm{K}$ menjadi salah satu unsur makro yang banyak dibutuhkan tanaman jika tidak diberikan secara cukup maka ketersediaan dan serapan N,P dan $\mathrm{K}$ rendah. Langkah awal yang dapat dilakukan dalam upaya meningkatkan hasil tanaman sawi pakcoy dan efisiensi serapan N, P dan $\mathrm{K}$ adalah dengan pemupukan berimbang. Penggunaan pupuk secara rasional dan berimbang merupakan salah satu faktor kunci untuk memperbaiki dan meningkatkan produktivitas lahan secara berkelanjutan. Pengelolaan hara terpadu mensyaratkan penggunaan pupuk organik dan anorganik sebagai sumber hara tanaman. Pengelolaan hara terpadu mensyaratkan penggunaan pupuk organik salah satunya menggunakan pupuk vermikompos yang berbahan dasar dari kotoran sapi yang telah diproses sedemikian rupa sehingga menjadi pupuk organik yang berkualitas dan unsur hara tersedia bagi tanaman.

Kualitas vermikompos ditentukam oleh komposisi kimia vermikompos terutama kandungan hara N, P dan K. Vermikompos mengandung N 2-3\%, P 1,55-2,25\% dan K $1,85-2,25 \%$ bergantung pada komposisi bahan atau media tumbuh cacing, spesies cacing yang digunakan dalam proses vermicomposting serta faktor lingkungan saat vermicomposting. Paramanik et al., (2007) melaporkan bahwa vermikompos yang berasal dari kotoran sapi memberikan peningkatan kandungan $\mathrm{N}$ tertinggi diikuti oleh limbah rumah tangga, residu rumput-rumputan dan gulma air dibandingan nilai awal bahan tersebut.

Beberapa hasil penelitian telah membuktikan aplikasi vermikompos pada tanaman hortikultura seperti strawberry terbukti meningkatkan ukuran buahnya dibanding dengan yang ditanam menggunakan pupuk organik (Arancon et al., 2004). Aplikasi vermikompos juga meningkatkan hasil dan kualitas tanaman sawi pakcoy, kubis dan brokoli (Nurhidayati et al., 2015 ; 2016 ; 2017). Hasil penelitian yang lain juga telah dilaporkan bahwa aplikasi vermikompos memberikan respon yang berbeda dari berbagai jenis tanaman bergantung pada kualitas vermikompos dan faktor lingkungan (Lazcano dan Dominguez, 2011).

\section{BAHAN DAN METODE}

Penelitian dilakukan di lahan Pertanian di Desa Landungsari Kecamatan Dau Kabupaten Malang dengan ketinggian $\pm 544 \mathrm{~m}$ dpl. Letak geografis daerah penelitian $7^{\circ} 21^{\prime}-7^{\circ} 31^{\prime}$ LS dan $110^{\circ} 10^{\prime}-111^{\circ} 40^{\prime}$ BT. Analisis tanaman dilakukan di Laboratorium 
Fisiologi Fakultas Pertanian Universitas Islam Malang dan analisis kadar hara dilakukan di Laboraturium Tanah Fakultas Pertanian Universitas Brawijaya.

Penelitian ini merupakan percobaan lapang menggunakan rancangan acak kelompok (RAK) faktorial dengan kontrol. Faktor 1 : Macam Bahan Vermikompos : $\mathrm{V}_{1}=$ sisa media jamur + kotoran sapi + seresah daun + jerami padi + sisa sayuran, $V_{2}=$ sabut kelapa + kotoran sapi + seresah daun + jerami padi + sisa sayuran dan $\mathrm{V}_{3}=$ serasah tebu + kotoran sapi + seresah daun + jerami padi + sisa sayuran Faktor 2 : Dosis Aplikasi : $D_{1}=5$ ton ha ${ }^{-1}, D_{2}=10$ ton ha ${ }^{-1}, D_{3}=15$ ton ha ${ }^{-1}$ dan $D_{4}=20$ ton ha ${ }^{-1}$. Variabel pertumbuhan yang diamati secara non destruktif meliputi jumlah daun, panjang tanaman dan luas daun, sedangkan variabel hasil diamati secara destruktif meliputi bobot segar total biomassa, bobot kering total biomassa, bobot yang bernilai ekonomis, indeks panen serta serapan hara N, P dan K. Data yang dihasilkan dianalisis ragam (ANOVA) dengan uji lanjut BNJ 5\% untuk mengetahui perbedaan antar perlakuan dan uji Dunnet 5\% untuk membandingkan perlakuan dengan kontrol. Analisis Regresi dilakukan untuk mencari dosis optimum vermikompos.

\section{HASIL DAN PEMBAHASAN}

\section{Pengaruh Macam Vermikompos pada Beberapa Dosis Aplikasi Terhadap Pertumbuhan Tanaman}

Hasil analisis ragam (Anova) menunjukkan tidak ada interaksi nyata antara macam vermikompos dan dosis aplikasinya terhadap panjang tanaman pada variabel pertumbuhan di akhir pengamatan (27 hst) (Tabel 1).

Tabel 1. Rata-rata variabel pertumbuhan umur 27 hst pada perlakuan macam bahan vermikompos dan dosis aplikasi

\begin{tabular}{cccc}
\hline \multirow{2}{*}{ Perlakuan } & \multicolumn{3}{c}{ Rata-rata Variabel Pertumbuhan $(27 \mathrm{hst})$} \\
\cline { 2 - 4 } & Jumlah daun (helai) & Panjang Tanaman $(\mathrm{cm})$ & Luas Daun $\left(\mathrm{cm}^{2}\right)$ \\
\hline $\mathrm{V}_{1}$ & 12.183 & $25.190 \mathrm{a}$ & $1613.990 \mathrm{a}$ \\
$\mathrm{V}_{2}$ & 12.233 & $26.005 \mathrm{~b}$ & $1847.440 \mathrm{~b}$ \\
$\mathrm{~V}_{3}$ & 12.250 & $24.793 \mathrm{a}$ & $1725.477 \mathrm{ab}$ \\
\hline BNJ 5\% & $\mathrm{TN}$ & 0.427 & 134.819 \\
\hline $\mathrm{D}_{1}$ & 12.067 & $24.576 \mathrm{a}$ & $1533.746 \mathrm{a}$ \\
$\mathrm{D}_{2}$ & 12.356 & $25.291 \mathrm{~b}$ & $1748.302 \mathrm{~b}$ \\
$\mathrm{D}_{3}$ & 12.533 & $25.649 \mathrm{~b}$ & $1890.894 \mathrm{~b}$ \\
$\mathrm{D}_{4}$ & 11.933 & $25.802 \mathrm{~b}$ & $1742.933 \mathrm{~b}$ \\
\hline BNJ 5\% & TN & 0.596 & 188.197 \\
\hline Keterangan : Angka yang didampingi huruf yang sama pada kolom yang sama menunjukkan \\
\multicolumn{4}{c}{ tidak berbeda nyata pada uji BNJ 5\%, TN : Tidak Nyata, BNJ : Beda Nyata } \\
Jujur, hst : hari setelah tanam.
\end{tabular}

Tabel 1. menunjukkan variabel pertumbuhan umur 27 hst perlakuan macam vermikompos berpengaruh nyata terhadap panjang tanaman dan luas daun dimana $V_{2}$ 
(sabut kelapa) memberikan panjang tanaman tertinggi mencapai 26,005 cm dan $1847,440 \mathrm{~cm}^{2}$ pada akhir pengmatan, sedangkan perlakuan dosis aplikasi berpengaruh nyata terhadap panjang tanaman dan luas daun dimana semakin tinggi dosis aplikasi semakin panjang tanaman, namun perlakuan $D_{2}\left(10\right.$ ton ha $\left.{ }^{-1}\right)$ dan $D_{4}(20$ ton $\mathrm{ha}^{-1}$ ) tidak berbeda nyata.

Tabel 2. menunjukkan bahwa variabel jumlah daun tidak berbeda nyata terhadap kontrol kecuali pada perlakuan $\mathrm{V}_{1} \mathrm{D}_{3}$ dan variabel panjang tanaman dan luas daun sebagian kombinasi perlakuan berbeda nyata dengan kontrol kecuali pada perlakuan $V_{1} D_{1}, V_{2} D_{1}, V_{3} D_{1}$ dan $V_{3} D_{2}$ untuk variabel panjang tanaman dan perlakuan $V_{1} D_{1}$ dan $V_{2} D_{1}$ pada variabel luas daun . 
Tabel 2. Rata-rata jumlah daun pada perlakuan macam bahan vermikompos dan dosis aplikasi setelah uji dunnet $5 \%$

\begin{tabular}{|c|c|c|c|}
\hline \multirow[b]{2}{*}{ Perlakuan } & \multicolumn{3}{|c|}{ Rata-rata Variabel Pertumbuhan (27 hst) } \\
\hline & Jumlah daun (helai) & Panjang Tanaman (cm) & $\begin{array}{l}\text { Luas Daun } \\
\text { (cm2) }\end{array}$ \\
\hline $\mathrm{V}_{1} \mathrm{D}_{1}$ & $\operatorname{tn} 12.267$ & tn 24.687 & tn 1510.870 \\
\hline$V_{1} D_{2}$ & tn 12.267 & * 24.933 & * 1619.720 \\
\hline$V_{1} D_{3}$ & * 12.733 & * 25.307 & * 1731.000 \\
\hline $\mathrm{V}_{1} \mathrm{D}_{4}$ & tn 11.467 & * 25.833 & * 1594.369 \\
\hline $\mathrm{V}_{2} \mathrm{D}_{1}$ & tn 11.733 & tn 24.640 & tn 1473.092 \\
\hline $\mathrm{V}_{2} \mathrm{D}_{2}$ & tn 12.333 & * 26.247 & * 1890.904 \\
\hline$V_{2} D_{3}$ & tn 12.400 & * 26.733 & * 2088.385 \\
\hline $\mathrm{V}_{2} \mathrm{D}_{4}$ & tn 12.467 & * 26.400 & * 1937.380 \\
\hline $\mathrm{V}_{3} \mathrm{D}_{1}$ & tn 12.200 & tn 24.400 & * 1617.276 \\
\hline$V_{3} D_{2}$ & tn 12.467 & tn 24.693 & * 1734.282 \\
\hline$V_{3} D_{3}$ & tn 12.467 & * 24.907 & * 1853.298 \\
\hline $\mathrm{V}_{3} \mathrm{D}_{4}$ & tn 11.867 & * 25.173 & * 1697.050 \\
\hline Kontrol & 11.667 & 23.907 & 1296.372 \\
\hline Dunnet 5\% & 0.847 & 0.806 & 254.842 \\
\hline
\end{tabular}

Berdasarkan hasil analisis statistik variabel pertumbuhan tanaman, secara umum perlakuan $\mathrm{V}_{2} \mathrm{D}_{3}$ (sabut kelapa + kotoran sapi + seresah daun + jerami padi + sisa sayuran dengan dosis 15 ton $^{\text {ha }}{ }^{-1}$ ) memberikan pertumbuhan terbaik, namun tidak berbeda nyata dengan perlakuan $\mathrm{V}_{2} \mathrm{D}_{2}$ (sabut kelapa + kotoran sapi + seresah daun + jerami padi + sisa sayuran dengan dosis 10 ton ha ${ }^{-1}$ ).

Perlakuan macam vermikompos $\mathrm{V}_{2}$ memiliki bahan dasar (bedding) sabut kelapa, berdasarkan analisis kimia media ini memiliki kandungan $\mathrm{N}$ paling tinggi yaitu sebesar 2,28\% (Tabel 8). Kandungan $\mathrm{N}$ sangat penting bagi pertumbuhan tanaman sayuran. Dalam sabut kelapa terkandung unsur-unsur hara dari alam yang sangat dibutuhkan tanaman yaitu berupa Kalium (K) yang dapat meningkatkan ketahanan tanaman dari kekeringan, hama dan penyakit. Disamping kandungan unsur-unsur lain seperti Kalsium (Ca), Magnesium (Mg), Natrium (Na) dan Fospor (P). Sabut yang mengandung $30 \%$ serat dengan komposisi kimia sabut kelapa terdiri atas selulosa, lignin, pyroligneous acid, gas, arang, tannin, dan potassium, kandungan unsur hara dan air dalam sabut kelapa adalah air 53,83\%, N: 0,28\% ppm, P:0 ppm, K: 6,726 ppm, Ca: 140 ppm, Mg: 170 ppm.

Beberapa efek tidak langsung dari vermikompos terkait dengan perubahan sifat mikrobiologi tanah. Aplikasi seperti substrat organik secara mikrobiologis mungkin memiliki efek penting pada sifat-sifat mikroba dari tanah atau media tanam sehingga 
mempengaruhi tanaman (Lores et al., 2006; Aira et al., 2007; Gómez-Brandon et al., 2010).

Beberapa hasil penelitian telah membuktikan bahwa aplikasi vermikompos pada tanaman hortikultura seperti strawberry terbukti meningkatkan ukuran buahnya dibanding dengan yang ditanam menggunakan pupuk anorganik tunggal (Arancón et al., 2006). Vermikompos dapat meningkatkan aktivitas mikroba serta meningkatkan biomassa mikroba. Kale et al., (1992) mengamati bahwa vermikompos dapat meningkatkan $\mathrm{N}$ secara signifikan lebih besar. Aktivitas enzim tanah juga meningkat secara signifikan dengan penambahan vermikompos dibandingkan dengan pupuk mineral (Marinari et al., 2000; Arancón et al., 2006; Saha et al., 2008.).

\section{Pengaruh Macam Vermikompos pada Beberapa Dosis Aplikasi Terhadap Hasil Tanaman Pakcoy}

Hasil analisis ragam (Anova) menunjukkan bahwa terdapat interaksi nyata antara macam vermikompos dan dosis aplikasi terhadap variabel hasil kecuali pada variabel indeks panen (Tabel 18).

Hasil uji Dunnet dengan taraf 5\% pada variabel hasil sebagian besar kombinasi perlakuan berbeda nyata dengan kontrol kecuali pada variabel berat kering total biomassa perlakuan $V_{2} D_{1}, V_{2} D_{4}, V_{3} D_{1}, V_{3} D_{3}$ dan $V_{3} D_{4}$. Pada variabel indeks panen hanya perlakuan $\mathrm{V}_{2} \mathrm{D}_{3}$ (sabut + kotoran sapi + seresah daun + jerami padi + sisa sayuran dengan dosis 15 ton ha ${ }^{-1}$ ) yang berbeda nyata dengan kontrol (Tabel 4). 
Tabel 4. Rata-rata hasil panen pada perlakuan macam bahan vermikompos dan dosis aplikasi setelah uji bnj 5\% dan uji dunnet 5\%

\begin{tabular}{|c|c|c|c|c|}
\hline \multirow[b]{2}{*}{ Perlakuan } & \multicolumn{4}{|c|}{ Rata-rata hasil panen } \\
\hline & $\begin{array}{c}\text { Bobot segar } \\
\text { total } \\
\text { biomassa } \\
(\text { ton ha-1) }\end{array}$ & $\begin{array}{c}\text { Berat yang } \\
\text { bernilai } \\
\text { ekonomis (ton } \\
\text { ha }^{-1} \text { ) }\end{array}$ & $\begin{array}{l}\text { Bobot kering } \\
\text { total biomassa } \\
\quad\left(\text { ton } \mathrm{ha}^{-1}\right)\end{array}$ & $\begin{array}{c}\text { Indeks } \\
\text { panen }(\%)\end{array}$ \\
\hline$V_{1} D_{1}$ & $* 47.806 \mathrm{a}$ & ${ }^{*} 43.152 \mathrm{ab}$ & * $4.401 \mathrm{ab}$ & tn 90.511 \\
\hline$V_{1} D_{2}$ & * $54.001 \mathrm{ab}$ & * $47.511 \mathrm{ab}$ & * $4.598 \mathrm{ab}$ & tn 88.137 \\
\hline$V_{1} D_{3}$ & * $54.337 \mathrm{ab}$ & * $50.640 \mathrm{abc}$ & * $4.331 \mathrm{ab}$ & tn 93.532 \\
\hline$V_{1} D_{4}$ & ${ }^{*} 51.009 \mathrm{a}$ & * $47.949 \mathrm{ab}$ & * $4.149 \mathrm{a}$ & tn 94.037 \\
\hline $\mathrm{V}_{2} \mathrm{D}_{1}$ & * $44.126 \mathrm{a}$ & ${ }^{*} 41.174 \mathrm{a}$ & tn $3.547 \mathrm{a}$ & tn 93.323 \\
\hline $\mathrm{V}_{2} \mathrm{D}_{2}$ & ${ }^{*} 64.535 \mathrm{~b}$ & ${ }^{*} 60.204 \mathrm{c}$ & ${ }^{*} 5.529 \mathrm{~b}$ & tn 93.252 \\
\hline $\mathrm{V}_{2} \mathrm{D}_{3}$ & * $54.488 \mathrm{ab}$ & * $51.901 \mathrm{bc}$ & * $4.704 \mathrm{ab}$ & * 95.440 \\
\hline$V_{2} D_{4}$ & * $52.796 \mathrm{a}$ & * $47.999 \mathrm{ab}$ & tn $3.739 \mathrm{a}$ & tn 90.873 \\
\hline$V_{3} D_{1}$ & * $48.160 \mathrm{a}$ & * $45.195 \mathrm{ab}$ & tn $3.753 \mathrm{a}$ & tn 93.822 \\
\hline$V_{3} D_{2}$ & * $50.044 \mathrm{a}$ & * $46.257 \mathrm{ab}$ & * $4.441 \mathrm{ab}$ & tn 92.609 \\
\hline$V_{3} D_{3}$ & * $51.616 \mathrm{a}$ & * $47.782 \mathrm{ab}$ & tn $3.604 \mathrm{a}$ & tn 92.759 \\
\hline $\mathrm{V}_{3} \mathrm{D}_{4}$ & * $46.384 \mathrm{a}$ & * $42.558 \mathrm{ab}$ & tn $3.494 \mathrm{a}$ & tn 92.177 \\
\hline Kontrol & 37.306 & 33.923 & 3.316 & 90.664 \\
\hline BNJ $5 \%$ & 11.246 & 9.851 & 1.297 & TN \\
\hline Dunnet $5 \%$ & 6.086 & 5.331 & 0.702 & 3.986 \\
\hline
\end{tabular}

Keterangan : Angka yang didampingi huruf yang sama pada kolom yang sama menunjukkan tidak berbeda nyata pada uji BNJ 5\%, TN : Tidak Nyata, BNJ : Beda Nyata Jujur, hst : hari setelah tanam. *: berbeda dengan kontrol.

Tabel 18 menunjukkan perlakuan $\mathrm{V}_{2} \mathrm{D}_{2}$ ( sabut kelapa + kotoran sapi + seresah daun + jerami padi + sisa sayuran dengan dosis 10 ton ha $^{-1}$ ) cenderung memberikan rata-rata produksi tertinggi, tetapi tidak berbeda nyata dengan $V_{1} D_{2}, V_{1} D_{3}$ dan $V_{2} D_{3}$ pada bobot segar total biomassa, tidak berbeda nyata dengan $V_{1} D_{3}$ dan $V_{2} D_{3}$ pada bobot yang bernilai ekonomis dan tidak berbeda nyata dengan $V_{1} D_{1}, V_{1} D_{2}, V_{1} D_{3}, V_{2} D_{3}$ dan $V_{3} D_{2}$ pada bobot kering total biomassa.

Hasil uji Dunnet 5\% pada Tabel 18 menunjukkan kombinasi perlakuan yang menggunakan vermikompos berbeda nyata dengan kontrol kecuali pada indeks panen. Hal ini menunjukan bahwa pada tanaman pakcoy berat akar relatif sama sehingga alokasi fotosintat lebih banyak ke bagian atas tanaman.

Hasil analisis ragam dengan uji BNJ 5\% menunjukkan bahwa perlakuan yang memberikan hasil tertinggi yaitu $\mathrm{V}_{2} \mathrm{D}_{2}$ (sabut kelapa + kotoran sapi + seresah daun + jerami padi + sisa sayuran dengan dosis 10 ton ha ${ }^{-1}$ ) memberikan rata-rata bobot segar total biomassa dan bobot yang bernilai ekonomis tertinggi yaitu 64,535 ton $\mathrm{ha}^{-1}$ dan 60,204 ton $\mathrm{ha}^{-1}$.

Menurut Manivannan et al., (2009) perbaikan pertumbuhan dan hasil tanaman akibat aplikasi vermikompos terjadi karena adanya perbaikan kualitas tanah dan 
ketersediaan hara mikro dan makro serta peningkatan aktivitas mikroba tanah. Romaniuk et al., (2011) menambahkan bahwa aplikasi vermikompos dapat memperbaiki sifat biokimia dan biologi tanah. Pori air tersedia dalam tanah juga meningkat, akibatnya kemampuan tanah dalam menyimpan air dan menyediakan ruang udara semakin baik. Hal ini menghindarkan cekaman kekeringan pada perakaran, sehingga pada perlakuan vermikompos dapat tumbuh dengan baik dibandingkan tanpa vermikompos. Tanaman yang diberi vermikompos memberikan hasil produksi yang lebih tinggi saat panen dibandingkan dengan tanaman yang tidak dipupuk dengan vermikompos.

\section{Dosis Optimum Vermikompos}

Uji regresi digunakan untuk menemukan dosis optimum penggunaan vermikompos pada tanaman pakcoy. Hasil uji regresi kuadaratik antara dosis aplikasi berbagai macam vermikompos $\left(\mathrm{V}_{1}, \mathrm{~V}_{2}\right.$ dan $\left.\mathrm{V} 3\right)$ terhadap berat hasil yang bernilai ekonomis terlihat pada Gambar 1.

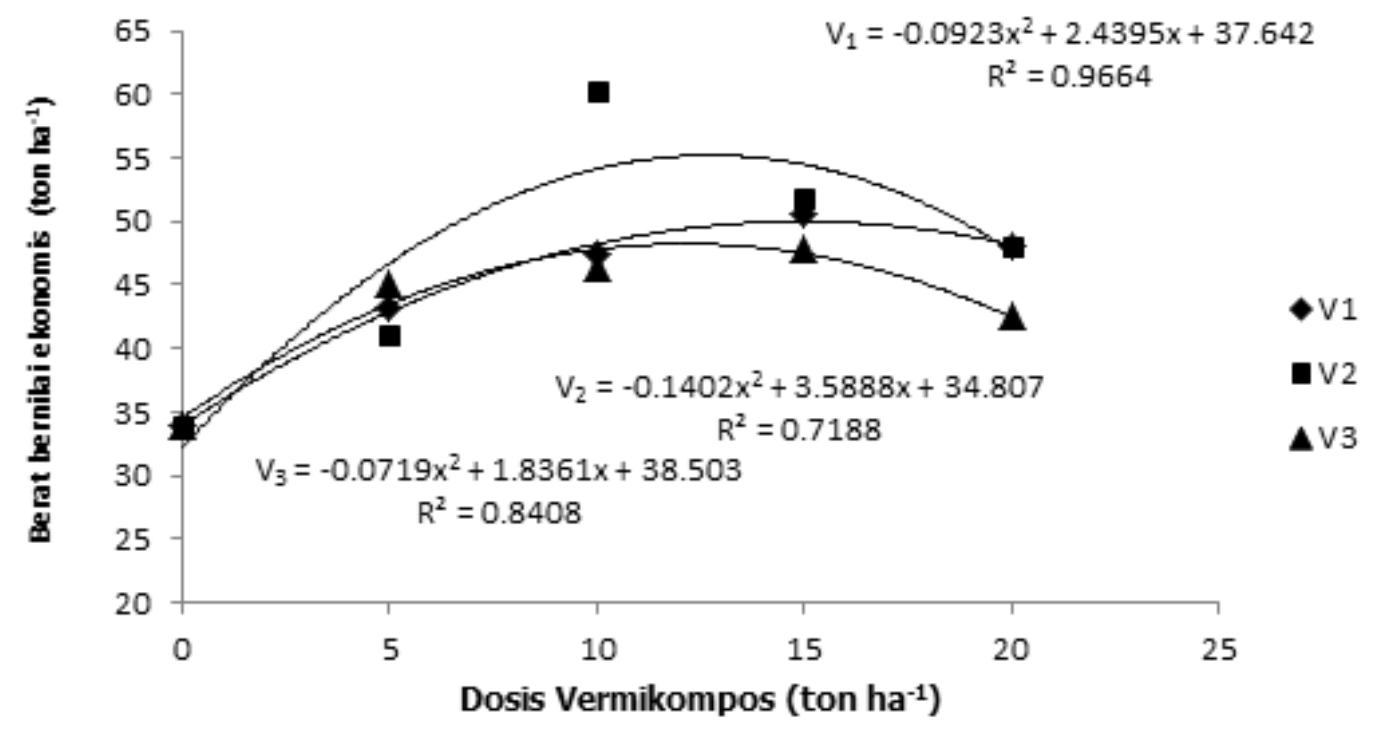

Gambar 1. Hubungan antara Dosis Vermikompos Dengan Berat Hasil yang Bernilai Ekonomis (ton ha $^{-1}$ ) pada Tiga Macam Vermikompos

Gambar 1 memperlihatkan bahwa hubungan antara dosis vermikompos dengan hasil yang bernilai ekonomis mengikuti pola kuadratik yang artinya semakin tinggi dosis sampai tingkat tertentu berat hasil yang bernilai ekonomis semakin meningkat. Hasil uji regresi menunjukkan bahwa tanaman pakcoy (Brassica rapa L.) yang diberi vermikompos dengan menggunakan bahan sabut kelapa + kotoran sapi + seresah daun + jerami padi + sisa sayuran $\left(V_{2}\right)$ dengan dosis optimum 12,799 ton ha ${ }^{-1}$ dapat meningkatkan produksi mencapai 57,773 ton ha ${ }^{-1}$ yang artinya semakin tinggi dosis 
sampai tingkat tertentu akan meningkatkan hasil. Selanjutnya jika melampaui titik optimum atau memberikan dosis yang lebih tinggi tanaman akan mengalami penurunan hasil.

\section{Pengaruh Macam Vermikompos pada Beberapa Dosis Aplikasi Terhadap Serapan Hara N, P dan K Tanaman Pakcoy}

Hasil analisis ragam (Anova) menunjukkan terdapat interaksi nyata antara macam vermikompos dan dosis aplikasi terhadap serapan hara N, P dan K (lampiran 5). Tabel 19. menunjukkan perlakuan $V_{2} D_{2}$ cenderung memberikan serapan hara $N, P$ dan $\mathrm{K}$ tertinggi. Hasil uji Dunnet $5 \%$ sebagian besar kombinasi perlakuan berbeda nyata dengan kontrol kecuali perlakuan $\mathrm{V}_{2} \mathrm{D}_{4}$ pada serapan $\left(\mathrm{N}\right.$ dan $\mathrm{P}$ ) dan $\mathrm{V}_{3} \mathrm{D}_{4}$ pada serapan $\mathrm{N}$ dan $\mathrm{K}$ (Tabel 5).

Tabel 5. Rata-rata serapan hara $\mathrm{n}, \mathrm{p}$ dan $\mathrm{k}$ pada perlakuan macam bahan vermikompos dan dosis aplikasi setelah uji bnj 5\% dan uji dunnet $5 \%$

\begin{tabular}{cccc}
\hline \multirow{2}{*}{ Perlakuan } & \multicolumn{3}{c}{ Rata-rata serapan hara $\left(\mathrm{gtan}^{-1}\right)$} \\
\cline { 2 - 4 } & ${ }^{*} 0.620 \mathrm{ab}$ & $\mathrm{P}$ & $\mathrm{K}$ \\
\hline $\mathrm{V}_{1} \mathrm{D}_{1}$ & ${ }^{*} 0.121 \mathrm{a}$ & ${ }^{*} 0.338 \mathrm{ab}$ \\
$\mathrm{V}_{1} \mathrm{D}_{2}$ & ${ }^{*} 0.666 \mathrm{ab}$ & ${ }^{*} 0.136 \mathrm{ab}$ & ${ }^{*} 0.376 \mathrm{ab}$ \\
$\mathrm{V}_{1} \mathrm{D}_{3}$ & ${ }^{*} 0.649 \mathrm{ab}$ & ${ }^{*} 0.141 \mathrm{ab}$ & ${ }^{*} 0.493 \mathrm{bc}$ \\
$\mathrm{V}_{1} \mathrm{D}_{4}$ & ${ }^{*} 0.552 \mathrm{ab}$ & ${ }^{*} 0.136 \mathrm{ab}$ & ${ }^{*} 0.425 \mathrm{ab}$ \\
$\mathrm{V}_{2} \mathrm{D}_{1}$ & ${ }^{\mathrm{tn}} 0.104 \mathrm{a}$ & ${ }^{*} 0.310 \mathrm{a}$ \\
$\mathrm{V}_{2} \mathrm{D}_{2}$ & ${ }^{*} 0.886 \mathrm{c}$ & ${ }^{*} 0.174 \mathrm{~b}$ & ${ }^{*} 0.636 \mathrm{c}$ \\
$\mathrm{V}_{2} \mathrm{D}_{3}$ & ${ }^{*} 0.736 \mathrm{bc}$ & ${ }^{*} 0.143 \mathrm{ab}$ & ${ }^{*} 0.453 \mathrm{ab}$ \\
$\mathrm{V}_{2} \mathrm{D}_{4}$ & ${ }^{\text {tn }} 0.517 \mathrm{a}$ & ${ }^{\mathrm{tn}} 0.103 \mathrm{a}$ & ${ }^{*} 0.351 \mathrm{ab}$ \\
$\mathrm{V}_{3} \mathrm{D}_{1}$ & ${ }^{*} 0.593 \mathrm{ab}$ & ${ }^{*} 0.124 \mathrm{a}$ & ${ }^{\mathrm{tn}} 0.299 \mathrm{a}$ \\
$\mathrm{V}_{3} \mathrm{D}_{2}$ & ${ }^{*} 0.665 \mathrm{ab}$ & ${ }^{*} 0.141 \mathrm{ab}$ & ${ }^{*} 0.436 \mathrm{ab}$ \\
$\mathrm{V}_{3} \mathrm{D}_{3}$ & ${ }^{*} 0.525 \mathrm{a}$ & ${ }^{*} 0.114 \mathrm{a}$ & ${ }^{*} 0.409 \mathrm{ab}$ \\
$\mathrm{V}_{3} \mathrm{D}_{4}$ & ${ }^{\mathrm{tn}} 0.496 \mathrm{a}$ & ${ }^{*} 0.119 \mathrm{a}$ & ${ }^{\mathrm{tn}} 0.326 \mathrm{a}$ \\
Kontrol & 0.413 & 0.085 & 0.245 \\
\hline BNJ 5\% & 0.198 & 0.043 & 0.158 \\
\hline Dunnet 5\% & 0.107 & 0.023 & 0.086
\end{tabular}

Keterangan : Angka yang didampingi huruf yang sama pada kolom yang sama menunjukkan tidak berbeda nyata pada uji BNJ 5\%, TN : Tidak Nyata, BNJ : Beda Nyata Jujur, hst : hari setelah tanam. *: berbeda dengan kontrol.

Tabel 5. menunjukkan hasil analisis uji BNJ 5\% pada serapan hara N, P dan $\mathrm{K}$ perlakuan $\mathrm{V}_{2} \mathrm{D}_{2}$ ( sabut kelapa + kotoran sapi + seresah daun + jerami padi + sisa sayuran dengan dosis 10 ton ha ${ }^{-1}$ ) cenderung memberikan serapan $\mathrm{N}, \mathrm{P}$ dan $\mathrm{K}$ yaitu $0,886 \mathrm{~g} \mathrm{tan}^{-1}, 0,174 \mathrm{~g} \mathrm{tan}^{-1}$ dan $0,636 \mathrm{~g} \mathrm{tan}^{-1}$, tetapi tidak berbeda nyata dengan $\mathrm{V}_{2} \mathrm{D}_{3}$ pada serapan $N$, tidak berbeda nyata dengan perlakuan $V_{1} D_{2}, V_{1} D_{3}, V_{2} D_{3}$ dan $V_{3} D_{2}$ 
pada serapan $P$ dan tidak berbeda nyata dengan perlakuan $V_{1} D_{3}$ pada serapan $K$. Hasil penelitian menunjukkan bahwa perlakuan $\mathrm{V}_{2} \mathrm{D}_{2}$ (sabut kelapa + kotoran sapi + seresah daun + jerami padi + sisa sayuran dengan dosis 10 ton ha ${ }^{-1}$ ) memberikan hasil tertinggi pada serapan hara $\mathrm{N}, \mathrm{P}$ dan $\mathrm{K}$ yaitu $0,886 \mathrm{~g} \mathrm{tan}^{-1}, 0,174 \mathrm{~g} \mathrm{tan}^{-1}$ dan 0,636 $\mathrm{g}$ $\tan ^{-1}$.

Berdasarkan analisis kimia vermikompos $\mathrm{V}_{2}$ yang berbahan dasar sabut kelapa memiliki kandungan $\mathrm{N}$ dan $\mathrm{K}$ relatif tinggi dibandingkan dengan $\mathrm{V}_{1}$ (sisa media jamur) dan $V_{3}$ (serasah tebu). Oleh karena itu $V_{2} D_{2}$ memberikan ketersediaan unsur hara yang tinggi bagi tanaman. Vermikompos mengandung $\mathrm{NO}_{3}^{-}$tinggi dibandingkan dengan kompos konvensional sehingga mudah diserap oleh tanaman.

Nurhidayati et al., (2008) menyatakan bahwa penambahan bahan organik ke dalam tanah dapat memperbaiki kualitas fisik dan biologi tanah seperti struktur tanah menjadi lebih remah, sehingga memudahkan akar tanaman menyerap unsur hara dari dalam tanah. Bahan organik dapat memperbaiki struktur tanah, meningkatkan kemampuan tanah dalam merangsang dan menyerap air, memperbaiki tata air dan sirkulasi udara tanah, sumber unsur hara, serta dapat mengurangi kehilangan air akibat evaporasi dan menjaga kelembaban tanah.

Aplikasi vermikompos juga dapat memperbaiki sifat kimia tanah dan ketersediaan $\mathrm{N}, \mathrm{P}$ dan K dalam tanah, serta meningkatkan populasi mikroba di dalam tanah (Pathma dan Sakthivel, 2012). Populasi mikroba yang meningkat (baik jenis dan jumlahnya) menyebabkan peningkatan mineralisasi bahan organik tanah dan ketersediaan hara bagi tanaman (Arancon et al., 2006). Kemampuan vermikompos untuk merubah sifat biologi tanah ke arah positif sehingga meningkatkan populasi mikroba yang menguntungkan tanaman menjadikan tanaman sawi tumbuh sehat dan berproduksi lebih tinggi dibandingkan dengan kontrol yang tidak dipupuk vermikompos. 


\section{KESIMPULAN DAN SARAN}

Pertumbuhan dan hasil tanaman terbaik terdapat pada perlakuan $\mathrm{V}_{2} \mathrm{D}_{2}$ (sabut kelapa + kotoran sapi + seresah daun + jerami padi + sisa sayuran dengan dosis 10 ton $\mathrm{ha}^{-1}$ ) memberikan rata-rata bobot segar total biomassa dan bobot yang bernilai ekonomis tertinggi yaitu 64,535 ton ha ${ }^{-1}$ dan 60,204 ton ha ${ }^{-1}$. Tingkat serapan hara N, P dan $\mathrm{K}$ tanaman sawi pakcoy (Brassica rapa L.) tertinggi pada perlakuan $\mathrm{V}_{2} \mathrm{D}_{2}$ (sabut kelapa + kotoran sapi + seresah daun + jerami padi + sisa sayuran dengan dosis 10 ton ha ${ }^{-1}$ ) yaitu sebesar $0,886 \mathrm{~g} \mathrm{tan}^{-1}, 0,174 \mathrm{~g} \mathrm{tan}^{-1}$ dan $0,636 \mathrm{~g} \mathrm{tan}^{-1}$. Dosis optimum untuk masing-masing vermikompos adalah $V_{1}=13,215$ ton ha ${ }^{-1}$ dengan hasil maksimum 53,761 ton ha ${ }^{-1}, V_{2}=12,799$ toh ha- ${ }^{-1}$ dengan hasil maksimum 57,773 ton ha $^{-1}$ dan $\mathrm{V}_{3}=12,768$ ton ha ${ }^{-1}$ dan hasil maksimum 50,225 ton ha ${ }^{-1}$. Untuk mendapatkan hasil sawi pakcoy yang tinggi dan berkualitas disarankan menggunakan pupuk organik vermikompos yang berbahan sabut kelapa, kotoran sapi, seresah daun, jerami padi, sisa sayuran dengan dosis 10 ton ha-1.

\section{DAFTAR PUSTAKA}

Aira, M., Monroy, F., Domínguez, J. 2007. Earthworms strongly modify microbial biomass and activity triggering enzymatic activities during vermicomposting independently of the application rates of pig slurry. Science of the Total Environment 385(1-3) : 252-261.

Arancon, N.Q., C.A. Edwards, P. Bierman, C. Welch and J.D. Metzger. 2004. Influences of vermicomposts on field strawberries-1: effects on growth and yields. Bioresource Technology. 93(2): 145-153.

Arancon, N.Q., C.A. Edwards, P. Bierman. 2006. Influences of vermicomposts on field strawberries: Part 2. Effects on soil microbiological and chemical properties. Bioresource Technology. 97(6) : 831-840.

Domínguez, J. 2004. State of the art and new perspectives on vermicomposting research. In: C.A. Edwards (Ed.). Earthworm Ecology (2nd edition). CRC Press LLC. Pp. 401-424.

Gomez-Brandon, M., C. Lazcano, J. Domingueza, 2008. Comparison of the effectiveness of composting and vermicomposting for the biological stabilization of cattle manure. Chemosphere. 72(7): 1013-1019.

Kale, R.D., B.C. Mallesh, B. Kubra, D.J. Bagyaraj. 1992. Influence of vermicompost application on the available macronutrients and selected microbial populations in a paddy field. Soil Biology and Biochemistry. 24(12) : 1317-1320.

Lazcano, C., and Domínguez, J. 2011. The use of vermicompost in sustainable agriculture: impact on plant growth and soil fertility. Soil nutrients. 10(1-23), 187.

Lores, M., M. Gómez-Brandón, D. Pérez-Díaz, J. Domínguez. 2006. Using FAME profiles for the characterization of animal wastes and vermicomposts. Soil Biology and Biochemistry. 38(9) : 2993-2996. 
Manivannan, S., M. Balamurugan, K. Parthasarathi, G. Gunasekaran, L.S. Ranganathan. 2009. Effect of vermicompost on soil fertility and crop productivity beans (Phaseolus vulgaris). Journal of Environmental Biology 30(2): 275-81.

Marinari, S., G. Masciandaro, B. Ceccanti, Grego, S. 2000. Influence of organic and mineral fertilizers on soil biological and physical properties. Bioresource Technology. 72(1) : 9-17.

Nurhidayati, Machfudz, M., Murwani, I. 2017. Pertumbuhan, hasil dan kualitas tanaman brokoli (Brassicace Oleraceae I.) sebagai respon terhadap aplikasi tiga macam vermikompos dengan sistem penanaman secara organik. Prosiding Seminar Nasional Fakultas Pertanian 2017. Fakultas Pertanian Universitas Nasional. ISBN : 978-602-61781-0-7.

Nurhidayati, N., Ali, U., \& Murwani, I. (2016). Yield and quality of cabbage (Brassica oleracea L. var. Capitata) under organic growing media using vermicompost and earthworm Pontoscolex corethrurus inoculation. Agriculture and Agricultural Science Procedia, 11, 5-13.

Nurhidayati, N., Usman, A., \& Murwani, I. (2017). Chemical Composition of Vermicompost Made from Organic Wastes through the Vermicomposting and Composting with the Addition of Fish Meal and Egg Shells Flour. The Journal of Pure and Applied Chemistry Research, 6(2), 127.

Nurhidayati, U. Ali, I. Murwani. 2015. Influence of the kind of vermikompost material and Earthworm Pontoscolex corethurus population on The Yield and Quality of Phak-Coi Mustard (Brassica rapa L.) with organic potting media. Proceeding of The First International Conference on Life Scince and Biotechnology Exploration and Conserfation of Biodiversity. ISBN : 978-602-9030-98-3.p.168176.

Pathma, J., \& Sakthivel, N. (2012). Microbial diversity of vermicompost bacteria that exhibit useful agricultural traits and waste management potential. SpringerPlus, 1(1), 1-19.

Pramanik, P., G.K. Ghosh, P.K. Ghosal and P. Banik. 2007. Changes in organic-C, N, P and $\mathrm{K}$ and enzymeactivities in vermicompost of biodegradable organic wastes under liming and microbial inoculants. Journal of Bioresource Technology. 98(13) : 2485-2494.

Romaniuk, R., Giuffré, L., Costantini, A., \& Nannipieri, P. (2011). Assessment of soil microbial diversity measurements as indicators of soil functioning in organic and conventional horticulture systems. Ecological Indicators, 11(5), 1345-1353. 